\title{
Explicit Corrective Feedback of English Statuses on Facebook: A Motivation or Demotivation in Updating Statuses in English as a Strategy for Practicing English
}

\author{
Noraziah Mohd Amin, Noor Azam Abdul Rahman, Wan Noorli Razali, Mohamad-Noor Sharipudin, \\ and Mohd Saifulnizam Abu Bakar
}

\begin{abstract}
It is argued that in language learning, learners receive encouragement for their correct productions of their second language (L2), and corrective feedback on errors made (Lightbown \& Spada, 2003) [1]. Explicit correction is defined by [1] as the explicit provision of the correct form of a language that involves a clear and elaborate description of the grammatical language production of a particular language element. As in the case of posting English statuses on Facebook, it is an issue of uncertainty whether this social networking site's users welcome the effort made by other users in correcting the former's grammatical errors explicitly or implicitly on Facebook, and subsequently whether these approaches can generate their motivation or demotivation in learning English. Therefore, this research intends to examine whether UNITEN students perceive being corrected explicitly with respect to their English statuses on Facebook as a motivational drive for them to improve their English or the opposite. The data was collected by administering questionnaires to 120 UNITEN students who actively posted their statuses in English on Facebook. The participants' responses towards the items investigated were analyzed using Statistical Package for Social Science (SPSS). It was revealed in the findings that the respondents in majority basically welcomed both explicit and implicit corrective feedback given by their Facebook friends as a response to the grammatical errors made by the respondents in updating their statuses in English on that social networking site especially in motivating them to write more statuses in English.
\end{abstract}

Index Terms-Corrective feedback, English learning, explicit corrective feedback, Facebook, implicit corrective feedback.

\section{INTRODUCTION}

It is uncertain whether Facebook users who are also English Second Language (ESL) learners welcome corrective feedback from their Facebook friends for their English statuses posted on this site. According to Vries, Cucchiarini, Strik and Hout (2013) [2], different types of feedback can

Manuscript received August, 2016, revised in October, 2016.

Noraziah Mohd Amin and Wan Noorli Razali are with Academy of Language Studies, Universiti Teknologi MARA (UiTM), Penang, Malaysia (e-mail: tinyfunnybunny7@gmail.com,

wannoorli093@ppinang.uitm.edu.my)

Noor Azam Abdul Rahman is with the Department of Social Sciences, Universiti Tenaga Nasional (UNITEN), Putrajaya, Malaysia (e-mail: azamabdulrahman@gmail.com).

Mohamad-Noor Sharipudin is with School of Multimedia Technology and Communication, Universiti Utara Malaysia (e-mail: mnsaleh@uum.edu.my).

Mohd Saifulnizam Abu Bakar is with the Department of Computer and Mathematical Sciences, Universiti Teknologi MARA (UiTM), Penang, Malaysia (e-mail: saifulnizam@gmail.com). give rise to a different impact on the process of language acquisition. As for the categories of corrective feedback, explicit or implicit feedback, [2] claim that there have been mixed findings in terms of whether explicit or implicit feedback is more effective despite the numerous studies conducted. They argue that there are indications that explicit corrective feedback is more effective than implicit one as the latter has the potential to be ambiguous (Bigelow, Delmas, Hansen \& Tarone, 2006) [3]. Therefore, the present research aims to investigate if the studied participants favor explicit or implicit feedback given to them for their English usage in the form of their English statuses posted on Facebook and the effectiveness of the feedback is examined in terms of how it manages to generate motivation in the learners to practice English (posting statuses in English). The findings of this study are expected to serve as additional information regarding this issue in the literature.

\section{A. Problem Statement}

According to Cook (2001) [4], in the context of language teaching, it has been a classical debate among scholars whether grammar should be explained to learners. Also, it is still uncertain whether second language learners of English favor the supply of explicit or implicit grammatical information. With respect to the use of new language learning platforms, based on the findings of the study conducted by Muhammad Kamarul Kabilan, Norlida Ahmad and Mohamad Jafre Zainol Abidin (2010) [5], it was discovered that the majority $(72 \%)$ of the participants expressed their agreement with Facebook being an environment for improving their motivation to interact in English. Despite such data, it is not of certainty that this is true for other people especially university students. Therefore, the present study was conducted in order to clarify these issues in the context of the utilization of Facebook by UNITEN students for learning English via feedback given to their statuses posted in English.

\section{B. Objectives of the Study}

It is very uncommon for a study to be conducted without any objectives. As for the present study, the researchers conducted the study to serve some purposes as follow:

1) To explore UNITEN students' perception towards using English in writing their statuses on Facebook.

2) To examine UNITEN students' perception towards implicit and explicit feedback given by their Facebook friends as a response to the grammatical errors in their English statuses posted on Facebook in relation to their motivation to practice English on Facebook. 


\section{Research Questions of the Study}

The research questions of this study were designed based on the objectives it aims to achieve and the questions are the followings:

1) What is UNITEN students' perception towards using English in writing their statuses on Facebook?

2) What is UNITEN students' perception towards implicit and explicit feedback given by their Facebook friends as a response to the grammatical errors in their English statuses posted on Facebook in relation to their motivation to practice English on Facebook?

\section{Significance of the Research}

As previously mentioned, the research intends to seek the answers to the issues focused on where the answers can contribute to adding more information to the fields or topics studied. Specifically, as Facebook is regarded as a platform for online social networking among university students that has gained the most popularity recently [5], the present study can perhaps be of an important source of extended knowledge about Facebook, particularly on how this social networking site can benefit university students in Malaysia (especially UNITEN) in English language learning.

\section{LITERATURE REVIEW}

\section{A. “Facebook” as a New Setting for Learning English}

Facebook was established in 2004 and its mission among others is to make people stay connected globally (newsroom.fb.com). In the statistics released by newsroom.fb.com, as of August 2016, it was discovered that there were 1.13 billion daily active users on average for June 2016, 1.03 billion mobile daily active users on average for June 2016, and approximately $84.5 \%$ of Facebook daily active users are outside the United States and Canada. According to Lempe, Ellison and Steinfield (2006) [6], a large number of students are active users of Facebook as they are always online on this social networking site. The study conducted by Wise, L. Z., Skues, J., \& Williams, B. (2011) [7] discovered that the first-year psychology students allocated an average of one hour a day on Facebook mainly for interacting socially with other users.

The interactive and collaborative nature of Facebook is claimed by Irwin, Ball, Desbrow and Leveritt (2012) [8] as they state, "Facebook is a website that allows users to interact and collaborate within a pre-defined virtual community" ( $p$. 1222). As for the aspect of language acquisition, Godwin-Jones (2008) [9] claims that Facebook is one of the tools and settings where human communication can be enhanced that this can possibly be employed for language learning. This idea is shared by Thanawan Suthiwartnarueput and Punchalee Wasanasomsithi (2012) [10] who claim that the functions of Facebook such as status updates, comments on others' posts and chat can help users in learning a language. The idea about the promotion of collaborative learning among users by Facebook through the target language discussions, negotiations, comments, questions, and status updates is also expressed by Terantino and Graf (2011) [11].

\section{B. Types of Corrective Feedback and Corrective Feedback as Part of Language Learning Process}

"Corrective feedback" is defined by [1] (p. 172) as, "an indication to learner that his or her use of the target language is incorrect." This includes a variety of responses that a language learner receives. [2] define corrective feedback as responses to the utterances produced by learners that contain an error. Ellis, Loewen and Erlam (2006) [12] classify corrective feedback into three groups of responses to learners: i) an indication that signifies an error has been committed by a learner, ii) provision of the correct form of the target language, and iii) metalinguistic details on the nature of the error committed, or any of these combined together.

In terms of the categories of corrective feedback, [1] argue that corrective feedback is of two categories: explicit corrective feedback that refers to overt supply of the correct form of language use, and implicit corrective feedback that may or may not comprise metalinguistic information as in the case of supplying information about the general grammatical rules (e.g: the verb should agree with the subject) rather than attending to the specific grammatical error made. Clearly, corrective feedback is part of language learning in the form of response to certain language use. [12] in their discussion on implicit and explicit learning, quote the definitions of these two types of learning provided by Ellis (1994, p. 2) [13] where implicit learning is described as "acquisition of knowledge about the underlying structure of a complex stimulus environment by a process that takes place naturally, simply and without conscious operations," while explicit learning refers to "a more conscious operation where the individual makes and tests hypotheses in search for a structure." Oxford (2011, p. 257) [14] in her definition of implicit learning explains that:

"Implicit L2 learning means learning grammar pattern without any direction to pay attention to form and without explanation of rules. Theoretically speaking, in implicit learning students develop competence without any awareness of linguistic targets or metalinguistic information, without intention and without consciousness."

To summarize, whether it is implicit or explicit is what differentiates corrective feedback where there is no obvious indication performed to show that an error has been committed for implicit feedback, while it is an opposite situation for explicit one, usually conducted in the form of recasts [12].

\section{Corrective Feedback and Motivation in Language Learning}

Vanpatten and Benati (2010) [15] in their discussion on learner differences explain how a set of personality and psycho-emotive characteristics are involved in learning something and how their learning is influenced by those characteristics including motivation. The level of a learner's desire to learn a language refers to their motivation that defines their achievement and development in the language [15]. According to Smith (2010) [16], since the study of Hendrickson in 1978 that showed his curiosity about whether errors should be corrected, as well as which, when and how the errors should be corrected, Corrective Feedback concept has been analyzed. Obviously, corrective feedback provided to learners can possibly result in some impact that it should be executed carefully for positive outcome. 
According to Russell (2009) [17], to keep students' affective filters low, structured grading as well as error correction is prohibited by the Natural Approach. [17] elaborates this issue by quoting Terrell (1977) [18] who views affective aspect as more important than cognitive one in language learning, and correcting students' errors as "negative in terms of motivation, attitude, \{and embarrassment" (p. 330). In contrast, Ellis (2009) [19] claims that Behaviorist and Cognitive theories perceive feedback as "contributing to language learning" (p. 3). [19] further mentions that in the Structural and Communicative approaches, feedback is positively accepted as it can generate learners' motivation and result in their linguistic accuracy. It was discovered that the learners in the study conducted by Abaya (2014) [20] favored explicit feedback more for the errors they made due to the fact that direct corrections were more noticeable which made it easy for them to take up the corrections.

\section{Methodology}

\section{A. Research Design}

A descriptive and quantitative research design using a questionnaire survey was employed in this study as well as there was no hypothesis postulated and tested.

\section{B. Participants}

The study involved 120 students who enrolled in degree programs of Mechanical Engineering, Civil Engineering, Electrical and Electronic Engineering, Power Engineering, as well as Computer Science and Information Technology from the Faculty of Engineering and the Faculty of Computer Science and Information Technology at Universiti Tenaga Nasional (UNITEN). There were 60 male and 60 female students aged between 19 to 23 years old participated in the study.

\section{Instrument}

The instrument used in the study was a questionnaire administered to each of the respondents. The questionnaire consisted of 32 self-reporting statements that described among others the respondents' perceptions towards posting statuses in English on Facebook and how they accepted the corrective feedback supplied by other Facebook users for the errors they made in their statuses. Such perceptions were measured using 5-point Likert Scale where numerical value was assigned to each level of agreement or disagreement with the statements or to a state of having no opinion at all: Strongly disagree $=1$, Disagree $=2$, Undecided $=3$, Agree $=4$, and Strongly agree $=5$.

\section{Data Collection}

The data collected from the questionnaires was entered into the Statistical Package for Social Sciences (SPSS) version 21. The quantitative data of this study was analyzed using SPSS version 17.0. There was no test-retest involved in the study as the data was collected in one stage only for the main study.

\section{1) The pilot study}

A pilot study was conducted with 30 students (15 males and 15 females) to test whether the questionnaire intended to be used by the researchers was reliable in terms of the questionnaire's reliability coefficient, item as well as instruction clarity and comprehensibility. The researchers explained the nature and purpose of the study to the participants prior to administering the questionnaires to them for a clarification of the study conducted. Next, the participants were given sufficient time to complete the questionnaires.

\section{2) The main study}

Basically, the same procedure performed in the pilot test was implemented in the main study except that the questionnaires were distributed to 120 respondents of the same population and background.

\section{FINDINGS AND ANALYSIS}

\section{A. Internal Consistency of the Pilot Study}

TABLE I: CRONBACH'S ALPHA RELIABILITY COEFFICIENT FOR THE

\begin{tabular}{|c|c|}
\hline \multicolumn{2}{|c|}{ INSTRUMENT } \\
\hline Reliability Statistics \\
\hline Cronbach's Alpha & No. of Items \\
\hline 0.776 & 32 \\
\hline
\end{tabular}

A pilot study was conducted to test the reliability of the items in the questionnaire with 30 respondents. The Cronbach's alpha value obtained was 0.776 which this indicated an acceptable value that showed the items in the questionnaire were reliable as well reasonable to be utilized for the present research.

\section{B. The Main Study}

1) Research question 1: What is UNITEN students' perception towards using English in writing their statuses on Facebook?

With regard to writing Facebook statuses in English, the majority of the respondents admitted that they always updated their statuses in English on Facebook as there was a huge percentage for their combined agreement and strong agreement (84.2\%) with item 1 ("I always write (update) my FB status using English"). The students in majority revealed that they preferred to ensure that their sentences are grammatically correct in updating Facebook statuses in English as $77.5 \%$ of them agreed with item 2 ("If I use English in writing my FB status, I will make sure my sentences are correct in terms of grammar").

In terms of the participants' perception towards making grammatical errors in their English statuses on Facebook, they provided positive feedback to items 7 ("If I write my FB statuses using English, I am not worried about the grammatical errors I make because my FB friends will certainly understand my English proficiency"), and 9 ("If I use English in writing my FB status, I am not worried about making grammatical errors as it is just an FB status") as they mostly agreed with these items with the percentages of $59.2 \%$ and $48.3 \%$ respectively. Thus, based on the results obtained, the respondents seemed to have mixed perception towards committing errors in their English status updates on Facebook as they claimed that errors should be avoided but at the same time, grammatical errors in Facebook statuses were deemed acceptable as they were not a serious issue.

Most of the respondents welcomed corrections of grammatical errors committed in writing statuses in English 
on Facebook as $52.5 \%$ of them agreed with item 5 ("Correcting the grammatical errors that are contained in FB statuses is the right action"). However, the results indicated a negative reaction by the majority of the participants towards grammatical error correction of English use in one's Facebook status performed in the comment section, as the percentage for the response option, "agree" contributed to item 8 ("I do not like it when my English grammatical errors are corrected in the comment section by my FB friends") was $75 \%($ mean $=4.16, \mathrm{SD}=0.55)$.

TABLE II: FREQUENCY (F) DistRIBUTION (IN PERCENTAGE) FOR THE RESPONDENTS' PERCEPTION TOWARDS USING ENGLISH IN WRITING THEIR STATUSES ON FACEBOOK $\mathbf{N}=\mathbf{1 2 0}$

\begin{tabular}{|c|c|c|c|c|c|c|c|c|}
\hline & Item & & & SD & D & $\mathbf{U}$ & $\mathbf{A}$ & SA \\
\hline No & $\begin{array}{l}\text { Use of English in writing } \\
\text { (update) status on } \\
\text { Facebook (FB). }\end{array}$ & Mean & $\begin{array}{l}\text { Std. } \\
\text { Dev }\end{array}$ & $\%$ & $\%$ & $\%$ & $\%$ & $\%$ \\
\hline 1 & $\begin{array}{l}\text { I always write (update) my FB } \\
\text { status using English. }\end{array}$ & 3.95 & 0.969 & 1.7 & 12.5 & 1.7 & 57.5 & 26.7 \\
\hline 2 & $\begin{array}{l}\text { If I use English in writing my } \\
\text { FB status, I will make sure my } \\
\text { sentences are correct in terms } \\
\text { of grammar. }\end{array}$ & 4.07 & 0.568 & 0 & 3.3 & 2.5 & 77.5 & 16.7 \\
\hline 5 & $\begin{array}{l}\text { Correcting the grammatical } \\
\text { errors that are contained in } \mathrm{FB} \\
\text { statuses is the right action. }\end{array}$ & 3.11 & 1.067 & 2.5 & 41.7 & 0.8 & 52.5 & 2.5 \\
\hline 7 & $\begin{array}{l}\text { If I write my FB statuses using } \\
\text { English, I am not worried } \\
\text { about the grammatical errors I } \\
\text { make because my FB friends } \\
\text { will certainly understand my } \\
\text { English proficiency. }\end{array}$ & 3.37 & 1.02 & 0 & 34.2 & 0.8 & 59.2 & 5.8 \\
\hline 8 & $\begin{array}{l}\text { I do not like it when my } \\
\text { English grammatical errors } \\
\text { are corrected in the comment } \\
\text { section by my FB friends. }\end{array}$ & 4.16 & 0.55 & 0 & 2.5 & 0.8 & 75 & 21.7 \\
\hline 9 & $\begin{array}{l}\text { If I use English in writing my } \\
\text { FB status, I am not worried } \\
\text { about making grammatical } \\
\text { errors as it is just an FB status. }\end{array}$ & 3.22 & 1.154 & 3.3 & 38.3 & 0.8 & 48.3 & 9.2 \\
\hline
\end{tabular}

2) Research Question 2: What is UNITEN students' perception towards implicit and explicit feedback given by their Facebook friends as a response to the grammatical errors in their English statuses posted on Facebook in relation to their motivation to practice English on Facebook?

When responding to items that asked about being corrected with detailed explanations of grammar for grammatical errors committed in writing English Facebook statuses, more than half of the respondents $(65=54.2 \%)$ agreed with item 11 ("I think I need to thank my FB friends who correct my grammatical errors in details in the comment section because I do not need to refer to books or the internet to learn about the errors anymore for this"), while $50.8 \%($ mean $=3, \mathrm{SD}=1.037$ ) disagreed with item 14 ("I think when my FB friends correct my English grammatical errors in my FB statuses in details, they just want to show off their English skills"), and the majority of them $(52.5 \%$ or 63 respondents) agreed with item 24 ("I think if my FB friend comments on my English grammatical error in details and my other FB friends also give the same comment, this can result in an English grammatical discussion that can help me learn English"). Most of the respondents believed that explicit corrective feedback given as a response to their ungrammatical English use in their Facebook statuses could be a motivational factor for them to practice their English more in writing statuses on that social networking site as the findings discovered that $48.3 \%$ (mean= $2.99, \mathrm{SD}=1.088$ ) of the respondents disagreed with item 16 , $51.7 \%$ (mean $=3.04, \mathrm{SD}=1.04)$ of them agreed with item 22 , and $51.7 \%$ (mean $=2.98, \mathrm{SD}=1.077)$ of them disagreed with item 23.

With respect to the participants' responses to implicit or indirect corrective feedback given for their grammatical errors in writing their statuses in English on Facebook, the respondents mostly did not favor implicit comments as they in majority $(51.7 \%$, mean $=2.99, \mathrm{SD}=1.088)$ disagreed with item 27 ("I would prefer if my FB friends give a comment like this: 'This sentence should be corrected in terms of the use of certain words' instead of 'This sentence needs correction in terms of the use of the word, 'fastly' because my FB friends can also learn together with me"), and the same percentage, $51.7 \%$ (mean $=2.97, \mathrm{SD}=1.053)$ of the respondents disagreed with item 29 ("I would prefer if my FB friend gives a comment like this: 'There's something incorrect in terms of grammar in this FB status of yours"'), and again similar percentage, $51.7 \%$ (mean $=2.97, \mathrm{SD}=1.053$ ) was contributed by the respondents who disagreed with item 31 ("I think indirect comments on my grammatical errors in my FB statuses written in English given by my FB friends is a way to help me identify the errors myself for me to learn about the errors independently"), but $50.8 \%$ of them agreed with item 30 ("Indirect comments provided by my FB friends on my grammatical errors in my FB statuses written in English will make me confused about their real intentions for giving such comments").

However, with regard to feeling motivated or demotivated to write more statuses in English after receiving implicit corrective feedback for grammatical errors that contained in their English Facebook statuses, the respondents seemed to admit that implicit feedback could motivate them to post more statuses in English on Facebook despite their preference for explicit corrective feedback. The respondents in majority (51.7\%) disagreed with item 28 ("I will not be motivated anymore to write my FB statuses in English when I get a comment on my FB status written in English like this: 'Did you check the grammar of this status?"'), and the same number of them $(62=51.7 \%)$ disagreed with item 32 ("I do not want to practice my English on FB anymore if my FB friend gives a comment like this: 'The grammatical error in this status of yours should not have happened' because he/she seems to belittle my English skills”).

\section{DISCUSSION AND CONCLUSION}

Ref. [12] argue that recasts (changes in the forms of language use) in explicit corrective feedback supply positive evidence. This is probably true as the results of this study indicated that majority of the students find that the corrections done explicitly or in details in the comment section to be helpful as they can be a good grammatical resource apart from saving the learners time and energy to look for explanations of the errors from some other sources. Besides, such corrections

supplied can be an avenue for grammatical discussions that can assist them in learning English. 
TABLE III: FREQUENCY (F) DISTRIBUTION (IN PERCENTAGE) FOR THE RESPONDENTS' PERCEPTION TOWARDS IMPLICIT AND EXPLICIT FEEDBACK GIVEN BY THEIR FB FRIENDS AS A RESPONSE TO THEIR GRAMMATICAL ERRORS IN THEIR ENGLISH STATUSES POSTED ON FACEBOOK IN RELATION TO THEIR MOTIVATION TO PRACTICE ENGLISH ON FACEBOOK $\mathbf{N}=\mathbf{1 2 0}$

\begin{tabular}{|c|c|c|c|c|c|c|c|c|}
\hline \multirow[b]{2}{*}{ No } & Item & \multirow[b]{2}{*}{ Mean } & \multirow[b]{2}{*}{$\begin{array}{l}\text { Std. } \\
\text { Dev }\end{array}$} & SD & D & $\mathbf{U}$ & $\mathbf{A}$ & SA \\
\hline & $\begin{array}{l}\text { Use of English in writing (update) } \\
\text { status on Facebook (FB). }\end{array}$ & & & $\%$ & $\%$ & $\%$ & $\%$ & $\%$ \\
\hline 11 & $\begin{array}{l}\text { I think I need to thank my FB friends } \\
\text { who correct my grammatical errors } \\
\text { in details in the comment section } \\
\text { because I do not need to refer to } \\
\text { books or the internet to learn about } \\
\text { the errors anymore for this. }\end{array}$ & 3.2 & 1.058 & 0.8 & 40.8 & 0 & 54.2 & 4.2 \\
\hline 14 & $\begin{array}{l}\text { I think when my FB friends correct } \\
\text { my English grammatical errors in } \\
\text { my FB statuses in details, they just } \\
\text { want to show off their English skills. }\end{array}$ & 3 & 1.037 & 0 & 50.8 & 0.8 & 45.8 & 2.5 \\
\hline 16 & $\begin{array}{l}\text { If my FB friends comment about my } \\
\text { grammatical errors in my FB } \\
\text { statuses written in English by } \\
\text { explaining the correct ways of using } \\
\text { certain forms, I will not feel } \\
\text { interested anymore to write my FB } \\
\text { statuses in English. }\end{array}$ & 2.99 & 1.088 & 2.5 & 48.3 & 0 & 45.8 & 3.3 \\
\hline 22 & $\begin{array}{l}\text { I do not think that the comments } \\
\text { given in details about my } \\
\text { grammatical errors in my FB } \\
\text { statuses written in English by my FB } \\
\text { friends is a way to demotivate me to } \\
\text { practice my English on Facebook. }\end{array}$ & 3.04 & 1.04 & 1.7 & 45.8 & 0 & 51.7 & 0.8 \\
\hline 23 & $\begin{array}{l}\text { I'm not confident anymore to learn } \\
\text { English after my grammatical errors } \\
\text { in my FB statuses written in English } \\
\text { are given explicit comments by my } \\
\text { FB friends in the comment section } \\
\text { because I think my English skills } \\
\text { seem to be belittled. }\end{array}$ & 2.98 & 1.077 & 0.8 & 51.7 & 0 & 43.3 & 4.2 \\
\hline 24 & $\begin{array}{l}\text { I think if my FB friend comments on } \\
\text { my English grammatical error in } \\
\text { details and my other FB friends also } \\
\text { give the same comment, this can } \\
\text { result in an English grammatical } \\
\text { discussion that can help me learn } \\
\text { English. }\end{array}$ & 3.04 & 1.016 & 0.8 & 46.7 & 0 & 52.5 & 0 \\
\hline 27 & $\begin{array}{l}\text { I would prefer if my FB friends give } \\
\text { a comment like this: "This sentence } \\
\text { should be corrected in terms of the } \\
\text { use of certain words" instead of } \\
\text { "This sentence needs correction in } \\
\text { terms of the use of the word, } \\
\text { "fastly"" because my FB friends can } \\
\text { also learn together with me. }\end{array}$ & 2.99 & 1.088 & 0.8 & 51.7 & 0 & 42.5 & 5 \\
\hline 28 & $\begin{array}{l}\text { I will not be motivated anymore to } \\
\text { write my FB statuses in English } \\
\text { when I get a comment on my FB } \\
\text { status written in English like this: } \\
\text { "Did you check the grammar of this } \\
\text { status?" }\end{array}$ & 2.95 & 1.028 & 0.8 & 51.7 & 0 & 46.7 & 0.8 \\
\hline 29 & $\begin{array}{l}\text { I would prefer if my FB friend gives } \\
\text { a comment like this: "There's } \\
\text { something incorrect in terms of } \\
\text { grammar in this FB status of yours." }\end{array}$ & 2.97 & 1.053 & 0.8 & 51.7 & 0 & 45 & 2.5 \\
\hline 30 & $\begin{array}{l}\text { Indirect comments provided by my } \\
\text { FB friends on my grammatical } \\
\text { errors in my FB statuses written in } \\
\text { English will make me confused } \\
\text { about their real intentions for giving } \\
\text { such comments. }\end{array}$ & 3.05 & 1.052 & 1.7 & 45.8 & 0 & 50.8 & 1.7 \\
\hline 31 & $\begin{array}{l}\text { I think indirect comments on my } \\
\text { grammatical errors in my FB } \\
\text { statuses written in English given by } \\
\text { my FB friends is a way to help me } \\
\text { identify the errors myself for me to } \\
\text { learn about the errors independently. }\end{array}$ & 2.97 & 1.053 & 0.8 & 51.7 & 0 & 45 & 2.5 \\
\hline 32 & $\begin{array}{l}\text { I do not want to practice my English } \\
\text { on FB anymore if my FB friend } \\
\text { gives a comment like this: "The } \\
\text { grammatical error in this status of } \\
\text { yours should not have happened" } \\
\text { because he/she seems to belittle my } \\
\text { English skills. }\end{array}$ & 2.95 & 1.028 & 0.8 & 51.7 & 0 & 46.7 & 0.8 \\
\hline
\end{tabular}

This study also shows that more than half of the students do not find implicit corrective feedback to be encouraging as revealed in their perception towards it as not a way to help the learners identify the errors themselves in order for them to learn about the errors autonomously. Carroll (2001) [21] argues that "most of the indirect forms of feedback do not locate the error" (p. 355). This perhaps can explain why implicit corrective feedback is not preferred due to the fact that it can contribute less to language learning in the context of identifying and localizing the errors made by learners and why the students favor explicit corrections more.

According to [8], a collaborative and cooperative learning experience can possibly be promoted by Facebook as a learning tool. Despite this fact, they propose more research to be implemented in order to obtain more insights on how this social networking site can improve learning. Thus, the function of Facebook as a tool for learning English and a source of motivation or demotivation to learn English through corrective feedback contributed by Facebook users should be further investigated for more supportive evidence of this issue so that language learning using this site can be enhanced.

\section{REFERENCES}

[1] P. M. Lightbown and N. Spada, How Languages Are Learned, Oxford, England: Oxford University Press, 2003.

[2] B. P. D. Vries, C. Cucchiarini, H. Strik, and R. V. Hout, The Role of Corrective Feedback in Second Language Learning: New Research Possibilities by Combining CALL and Speech Technology, Centre for Language and Speech Technology, Radboud University Nijmegen, the Netherlands, 2013.

[3] M. Bigelow, R. Delmas, K. Hansen, and E. Tarone, "Literacy and the processing of oral recasts in SLA," TESOL Quarterly, vol. 40, no. 4, pp. 665-685, 2006.

[4] V. Cook, Second Language Learning and Language Teaching, London: Arnold, 2001

[5] M. K. Kabilan, N. Ahmad, and M. J. Z. Abidin. (2010). Facebook: An Online Environment for Learning of English in Institutions of Higher Education? Internet and Higher Education. [Online]. Available: http://teslcanadajournal.ca/index.php/tesl/article/viewFile/1175/995

[6] C. Lempe, N. Ellison, and C. Steinfield, "A facebook in the crowd: Social searching vs. social browsing," in Proc. the 20th Anniversary Conference on Computer Supported Cooperative Work, Banff, Alberta, Canada, 2006.

[7] L. Z. Wise, J. Skues, and B. Williams. (2011). Facebook in higher education promotes social but not academic engagement. In Changing demands, changing directions. [Online] Available: http://www.ascilite.org.au/conferences/hobart11/downloads/papers/W ise-full.pdf

[8] C. Irwin, L. Ball, B. Desbrow, and M. Leveritt, "Students' perceptions of using Facebook as an interactive learning resource at university," Australasian Journal of Educational Technology 2012, vol. 28, no. 7, pp. 1221-1232, 2012.

[9] R. G. Jones, "Mobile computing technologies: Lighter, faster, smarter," Language Learning and Technology, vol. 12, no. 3, pp. 3-9, 2008.

[10] T. Suthiwartnarueput and P. Wasanasomsithi. (2012). Effects of Using Facebook as a Medium for Discussions of English Grammar and Writing of Low-Intermediate EFL Students. Electronic Journal of Foreign Language Teaching. (C) Centre for Language Studies National University of Singapore. [Online]. Available: http://e-flt.nus.edu.sg/v9n22012/suthiwartnarueput.pdf

[11] J. Terantino and K. Graf, ( November 2011). In the classroom: Using Facebook in the language classroom as part of the net generation curriculum. The Language Educator. [Online]. Available: http://www.actfl.org/files/TLEsamples/TLE_Nov11_Article.pdf

[12] E. L. Erlam. (2006). Implicit and explicit corrective feedback and the acquisition of L2 grammar. SSLA. [Online]. 28, pp. 339-368. Available: https://www.cambridge.org/core/services/aop-cambridge-core/content /view/CDE67D4A4E286921DA4BE9C40BAD9FE6/S02722631060 60141a.pdf/implicit-and-explicit-corrective-feedback-and-the-acquisi tion-of-12-grammar.pdf

[13] N. C. Ellis, "Introduction: Implicit and explicit language learning: An overview," Implicit and Explicit Learning of Languages, San Diego, CA: Academic Press, pp. 1-31, 1994.

[14] R. L. Oxford, Teaching and Researching Language Learning Strategies, United Kingdom: Pearson Education Limited, 2011. 
[15] B. VanPatten and A. G. Benati, Key Terms in Second Language Acquisition, London: Continuum International Publishing Group, 2010.

[16] H. Smith, Correct Me If I" $m$ Wrong: Investigating the Preferences in Error Correction among Adult English Language Learners, M. A. Thesis. University of Denver, 2010.

[17] V. Russell. (2009). Corrective feedback, over a decade of research since Lyster and Ranta (1997): Where do we stand today? Electronic Journal of Foreign Language Teaching, () Centre for Language Studies National University of Singapore. [Online]. Available: http://e-flt.nus.edu.sg/v6n12009/russell.pdf

[18] T. Terrell. (1977). A natural approach to second language acquisition and learning. The Modern Language Journal. [Online]. 61, pp. 325-337.

Available: https://www.jstor.org/stable/324551?seq=1\#page_scan_tab_contents

[19] R. Ellis. (2009). Corrective Feedback and Teacher Development. L2 Journal. [Online]. http://escholarship.org/uc/item/2504d6w3\#page-1

[20] R. Abaya. (2014). Corrective feedback in English language teaching and Learning: Which way to Go? International Journal on Studies in English Language and Literature (IJSELL). [Online]. Available: https://www.arcjournals.org/pdfs/ijsell/v2-i10/2.pdf

[21] S. Carroll, Input and Evidence: The Raw Material of Second Language Acquisition, Amsterdam: Benjamins, 2001.

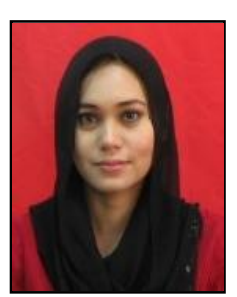

Noraziah Mohd Amin is an English lecturer from the Academy of Language Studies, UiTM Penang. She completed her bachelor's degree in English language and literature at UIAM and her Master's Degree in Applied Linguistics at UUM. She has been teaching English for more than eight years and has her academic research and articles as well as creative writings published locally and internationally.

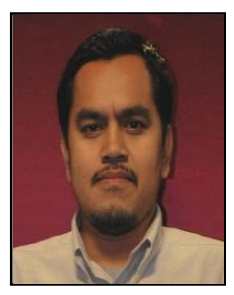

Noor Azam Abdul Rahman is a senior lecturer and the head of Department Social Sciences, University Tenaga Nasional (UNITEN), Putrajaya Malaysia. He was graduated master's degree and a bachelor's degree in Malays studies with a concentration on Malay Language from University of Malaya, Kuala Lumpur. $\mathrm{He}$ has a 15 year teaching experience at higher education institution. At the moment, he is actively involved in teaching and researching with respect social sciences area such as languages, cultures, education, teaching and learning, leadership and motivation.

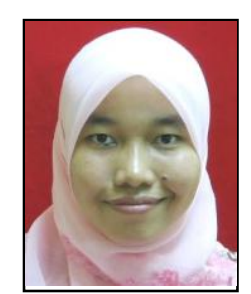

Wan Noorli Razali is an English lecturer at the Academy of Language Studies, UiTM Pulau Pinang. She received her degree in English language and literature from International Islamic University Malaysia and her master of arts in linguistics and English language studies from Universiti Sains Malaysia. Her research interests include English as second language and language learning strategies.

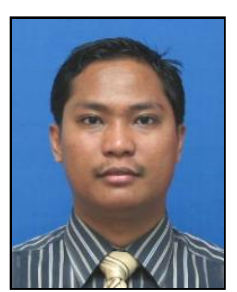

Mohamad-Noor Sharipudin is lecturer at Universiti Utara Malaysia from the School of Multimedia Technology and Communication. He obtained his BA in communication from Universiti Putra Malaysia and graduated from the same university with an MA in corporate communication. At the moment, he is completing his Ph.D at Victoria University of Wellington, New Zealand. His research interests are social sponsorship, branding, consumer behaviour, social media. 